\title{
Statistical Analysis Between the Routes of Administration of L-Dopa and Digestive Dysfunctions in Parkinson Disease
}

\author{
OANA CRICIOTOIU ${ }^{1}$, DIANA IULIA STANCA ${ }^{2 *}$, DANIELA-GABRIELA GLAVAN ${ }^{3}$, CECIL SORIN MIREA ${ }^{4}$, ADRIAN MITA ${ }^{5}$, \\ VERONICA CALBOREAN ${ }^{1}$, VICTOR GHEORMAN ${ }^{3}$, ION UDRISTOIU ${ }^{3}$, ANDA LORENA DIJ MARESCU, \\ DRAGOS VIRGIL DAVITOIU', DAN IONUT GHEONEA ${ }^{8}$ \\ ${ }^{1}$ University of Medicine and Pharmacy of Craiova, Doctoral School, 2 Petru Rares Str., 200349, Craiova, Romania \\ 2 University of Medicine and Pharmacy of Craiova, Faculty of Medicine, Department of Neurology, 2 Petru Rares Str., 200349, \\ Craiova, Romania \\ ${ }^{3}$ University of Medicine and Pharmacy of Craiova, Faculty of Medicine, Department of Psychiatry, 2 Petru Rares Str., 200349, \\ Craiova, Romania \\ ${ }^{4}$ University of Medicine and Pharmacy of Craiova, Surgery Department, County Hospital of Craiova, 1 Tabaci Str., 200642, Craiova, \\ Romania \\ ${ }^{5}$ University of Medicine and Pharmacy of Craiova, Faculty of Medicine, Department of Internal Medicine, 2 Petru Rares Str., \\ 200349, Craiova, Romania \\ ${ }^{6}$ University of Medicine and Pharmacy of Craiova, Obstretics-Gynecology Department, Filantropia Clinical Hospital of Craiova, \\ 1 Filantropiei Str., 200143, Craiova, Romania \\ 7 University of Medicine and Pharmacy of Bucharest, Surgery Department, Clinical Emergency Hospital Sf. Pantelimon Bucharest, \\ 340-343 Pantelimon Road, 021659, Bucharest, Romania \\ ${ }^{8}$ University of Medicine and Pharmacy of Craiova, County Hospital of Craiova, Gastroenterology Department, 1 Tabaci Str., \\ 200642, Craiova, Romania
}

The aim of this study was to evaluate possible correlation between routes of administration of levodopa in patients diagnosed with Parkinson's disease and the presence of digestive symptoms. We included in this study 31 patients diagnosed with Parkinson's disease:14 patients were on oral levodopa and 17 patients were on intrajejunal administration of levodopa/carbidopa. Each patient was assessed using Non-motor Symptoms Questionnaire for Parkinson's Disease regarding the dysfunction of gastrointestinal tract. The results of our study indicated that there is a different distribution of the digestive dysfunction between the two groups of patients. The study indicate that the constipation was more frequent in those patients with oral medication.

Keywords: levodopa, oral administration, intrajejunal gel, Parkinson's disease

Parkinson's disease (PD) belongs to the main group of neurodegenerative disorders, being the second most common neurodegenerative disorder, that was primarily characterized by motor signs including bradykinesia, resting tremor and muscle rigidity. This concept has been changed mainly in the 21 st century and, at this moment, $P D$ is regarded as much a non-motor disorder $[1,2,19]$.

The importance of non-motor symptoms (NMS) for patients with Parkinson's disease was highlighted by reports which have suggested the serious social and economic consequences related to NMS, frequently causing hospitalization and institutionalization [ 3,4].

NMS include 10 domains ranging from dysfunction of gastrointestinal tract to miscellaneous (diplopia, weight loss), and - as reported by a European study, more than $90 \%$ of patients did not mention or discuss the NMS they are experiencing until the clinicians became aware of them [5].The presence of NMS in the clinical presentation of PD patients has been accompanied by a trend towards a more patients-centered approach to the diagnosis and treatment of the disease [6].

Levodopa, the precursor of dopamine, is an aromatic amino acid that was introduced into the treatment of patients in the first years of 1960s and is, until now, considerate the gold standard among antiparkinsonian drugs [7].It has a marked symptomatic effect on all components of the cardinal parkinsonian motor signs, but to a lesser extent, on non-motor symptoms [8] .
Until now, there are two manner in which levodopa can be administrated: oral administration and intrajejunal infusion.

In our study, we wanted to evaluate the presence of gastrointestinal dysfunction in patients with PD and the degree of these dysfunction depending on the route of levodopa administration.

\section{Experimental part}

\section{Methods and materials}

31 patients diagnosed with advanced Parkinson's disease established by Movement Disorder Society Clinical Diagnostic Criteria for Parkinson's disease were included in this study [9]. They were divided in 2 groups: group A composed of 14 patients ( 10 men and 4 women, with a mean age 69.7) that were treated with oral levodopa and 17 patients ( 8 men and 9 women, with a mean age 65.3) treated with levodopa/carbidopa intrajejunal infusion.

All patients were evaluated in best on state for motor status using Unified Parkinson's Disease Rating Scale (UPDRS) part 3 (motor part), healthy related quality of life with PDQ-8 (8-item Parkinson's Disease Questionnaire) [10].

To evaluate the non-motor symptoms, each patient was assessed by Non-motor Symptoms Questionnaire for Parkinson's Disease (NMS Quest) [11].The NMS Quest is recommended by international societies for use in Parkinson's disease patients to assess the non-motor 
symptoms. It is a self-assessing tool that includes 30 questions covering 10 different domains ranging from gastrointestinal to miscellaneous [1].

The gastrointestinal domain includes dribbling of saliva, ageusia, dysphagia/choking, vomiting/nausea, constipation, unsatisfactory voiding of bowel and fecal incontinence. This questionnaire must be completed by the patient, checking the no or yes box. We rated 0 point if the patient's answer was no and 1 point if the patient's answer was yes.

The statistical analysis was made using IBM SPSS Statistics V20. We performed both descriptive and exploratory data analysis.

For comparations we used one tailed studentt-test and for correlation - Pearson R test, with the statistical significance established when $p<0.05$.

The analysis of the digestive domain showed a distinct distribution in the two groups.

We can see in the graph below that except the ageusia, all the digestive symptoms have an increased frequency in patients treated with oral levodopa.

The greatest difference appears to be on the vomiting/ nausea, constipation and the unsatisfactory voiding of bowel (fig. 1).

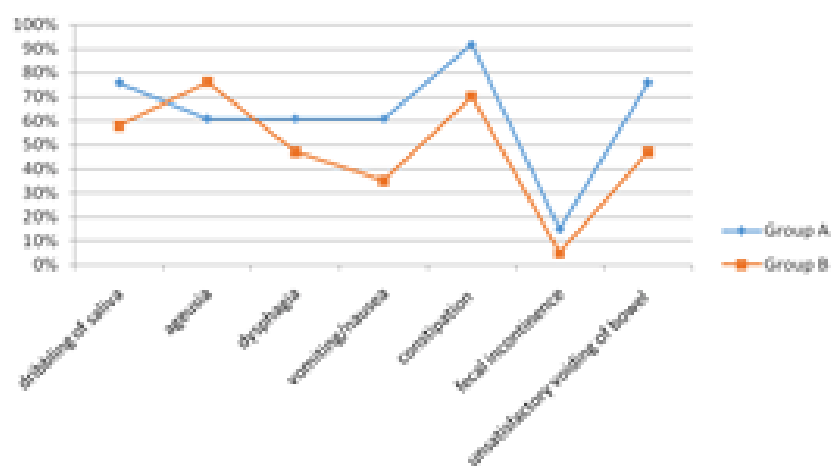

Fig. 1. Distribution of digestive symptoms in group $A$ and $B$

After the results of the descriptive statistics of our data we performed a one sample $t$ test. The hypothesis tested was that the patients in group A had more prevalent digestive symptoms then group $B$.

As we can see in the figure below the distribution of the two groups is significant with a $p$ value $<0.001$. this means that our hypothesis is true and there is a statistically significant difference between the different routes of administration. (table 1, fig. 2)

When comparing the prevalence of the digestive symptoms and the quality of life assessed by PDQ-8 questionnaire, there was a difference between the two groups. The first group's digestive symptoms did not present a statistically significant correlation $p=0.30$ with the PDQ8 (table 2, fig. 3).

Table 1

t-TEST TABLE FOR COMPARATION BETWEEN DIGESTIVE SYMPTOMS IN GROUP A AND B

One-Sample Test

\begin{tabular}{|c|c|c|c|c|c|c|}
\hline & \multicolumn{6}{|c|}{ TestValue = 1} \\
\hline & \multirow[b]{2}{*}{1} & \multirow[b]{2}{*}{ d } & \multirow[b]{2}{*}{ Sig. (2.talso) } & \multirow{2}{*}{$\begin{array}{c}\text { Nean } \\
\text { Difference }\end{array}$} & \multicolumn{2}{|c|}{$\begin{array}{l}95 \% \text { Confdence intental of the } \\
\text { Difference }\end{array}$} \\
\hline & & & & & Lowet & Upper \\
\hline Digystive_smplomms & 10.483 & 30 & .000 & 2.839 & 229 & 3.3 \\
\hline Administzason form & 6036 & 30 & .000 & .548 & .36 & .73 \\
\hline
\end{tabular}

\section{Results and discussions}

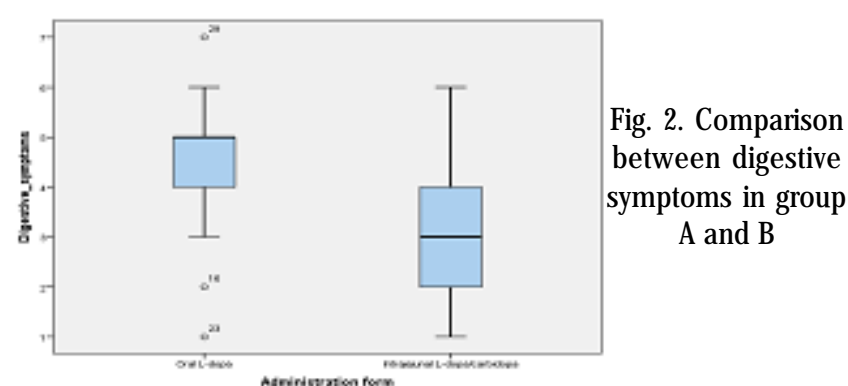

Table 2

PEARSON CORRELATION TABLE BETWEEN DIGESTIVE SYMPTOMS AND QOL IN GROUP A

Correliations

\begin{tabular}{|c|c|c|c|}
\hline & & $\begin{array}{c}\text { Digestive_sy } \\
\text { mpsoms }\end{array}$ & PDos \\
\hline \multirow[t]{3}{*}{ Digestive_symbtoms } & Pearson Correlaton & 1 & 297 \\
\hline & Sig. (2-talpd) & & .302 \\
\hline & $N$ & 14 & 14 \\
\hline \multirow[t]{3}{*}{ POOB } & Parsan Correlaton & 297 & 1 \\
\hline & Sig. (2-alpd) & .302 & \\
\hline & $N$ & 14 & 14 \\
\hline
\end{tabular}

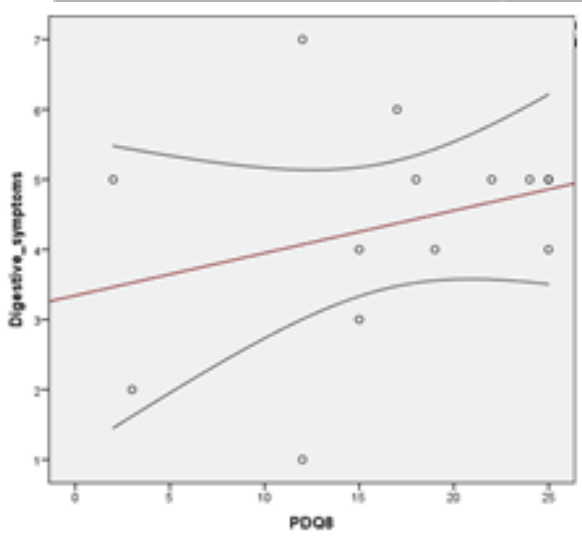

Fig. 3. Correlation between digestive symptoms and Qol in group $\mathrm{A}$

On the other side, in group B the Quality of life decreased as the prevalence of digestive symptoms increased. That show ed a positive correlation with $p=0.02$ (table 3, fig. 4).

We compared the prevalence of digestive symptoms with the motor disfunction, assessed with UPDRS part III, in the 2 groups.

Table 3

PEARSON CORRELATION TABLE BETWEEN DIGESTIVE SYMPTOMS AND QOL IN GROUP B

\begin{tabular}{|ll|r|r|}
\hline & \multicolumn{1}{|c|}{$\begin{array}{c}\text { Digestive_sy } \\
\text { mptoms }\end{array}$} & \multicolumn{1}{c|}{ PDQ8 } \\
\hline Digestive_symptoms & Pearson Correlation & 1 & .415 \\
& Sig.(2-tailed) & 31 & .020 \\
& N & 31 \\
\hline PDQ8 & Pearson Correlation & .415 & 1 \\
& Sig. (2-tailed) & .020 & \\
& N & 31 & 31 \\
\hline
\end{tabular}

*. Correlation is significant at the 0.05 level (2-tailed).

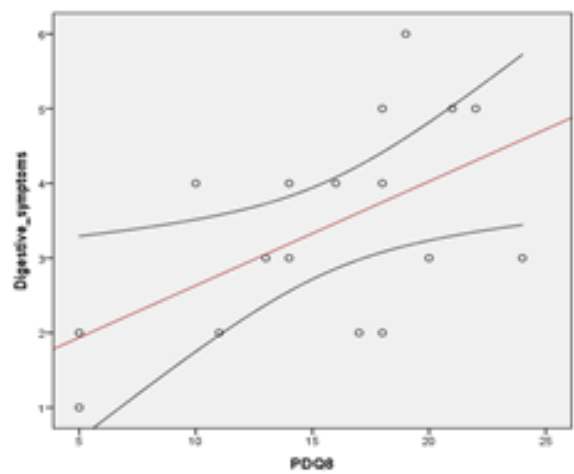

Fig. 4. Correlation between digestive symptoms and Qol in 
Group A did not presenta difference between the motor and digestive dysfunction, in the second group there was a difference, but not statistically significant with $P=0.06$.

Digestive dysfunction plays an important role in PD patients and it is present from the early state of the disease [12]. Early involvement of the gut is considered to be a possible pre-symptomatic state of PD [13].

Constipation is considered to be present in over $50 \%$ of PD patients. It is used as a potential biomarker for prodromal Parkinson's disease [14].

L-dopa administration represent the gold standard in PD treatment. Sustained striatal dopamine level with continuous L-dopa/carbidopa intrajejunal administration showed superior to oral medication. It improved both motor and non-motor symptoms [15].

Our study also showed decreased trend in the frequencies of digestive symptoms of these patients when compared with patients on oral medication.

The markers that contribute to decreased the quality of life is stigma, memory loss, motor impairment and digestive dysfunction, especially drooling $[16,17]$. In our analysis the digestive dysfunction only correlated with the quality of life in patients with continuous administration of L-dopa/carbidopa.

The autonomic features are heterogeneous distributed and as in the larger studies, in our study it is not correlate with the motor symptoms [18].

\section{Conclusions}

Our study indicates that the frequency of digestive symptoms is hire in patients with oral medication, especially vomiting/nausea, constipation and the unsatisfactory voiding of bowel.

\section{References}

1.TODOROVA, A., J ENNER, P., AND RAY CHAUDHURI, K., Non-motor Parkinson's: integral to motor Parkinson's, yet often neglected., Practical neurology, vol. 14, 2014, p. 310-22.

2.CHAUDHURI, K. R., HEALY, D. G., SCHAPIRA, A. H., and National Institute for Clinical Excellence, Non-motor symptoms of Parkinson's disease: diagnosis and management, The Lancet Neurology, vol. 5, 2006, p. 235-245.

3.RIOS ROMENETS, S., WOLFSON, C., GALATAS, C., PELLETIER, A., ALTMAN, R., WADUP, L., and Postuma, R. B., Validation of the nonmotor symptoms questionnaire (NMS-Quest), Parkinsonism \& Related Disorders, vol. 18, 2012, p. 54-58.

4.TODOROVA, A., JENNER, P., RAY CHAUDHURI, K., Non-motor parkinson's: Integral to motor parkinson's, yet often neglected, Practical Neurology, vol. 14, 2014, p. 310-322.

5.EVATT, M. L., CHAUDHURI, K. R., CHOU, K. L., CUBO, E., HINSON, V., KOMPOLITI, K., YANG, C., POEWE, W., RASCOL, O., SAMPAIO, C., STEBBINS, G. T., GOETZ, C. G., Dysautonomia rating scales in Parkinson's disease: sialorrhea, dysphagia, and constipation-critique and recommendations by movement disorders task force on rating scales for Parkinson's disease., Movement disorders: official journal of the Movement Disorder Society, vol. 24, 2009, p. 635-46.

6.BREEN, K. C., DRUTYTE, G., Non-motor symptoms of Parkinson's disease: the patient's perspective, Journal of Neural Transmission, vol. 120, 2013, p. 531-535.

7.LEDETI, A., VLASE, G., CIRCIOBAN, D., LEDETI, I., STELEA, L., AND VLASE, T., Comparative Stability of Levodopa Under Thermal Stress in both Oxidative and Inert Media, Rev. Chim. (Bucharest), 67, 2016, p. 2648-2650.
8.WARD, A.-8-L., AND HOSPITAL, T., Global long-term study on motor and non-motor symptoms and safety of levodopa-carbidopa intestinal gel in routine care of advanced Parkinson's disease patients; 12month interim outcomes-NC-ND license (http://creativecommons.org/ licenses/by-nc-nd/4.0/), 2015.

9.POSTUMA, R. B., BERG, D., STERN, M., POEWE, W., OLANOW, C. W., OERTEL, W., OBESO, J., MAREK, K., LITVAN, I., LANG, A. E., HALLIDAY, G., GOETZ, C. G., GASSER, T., DUBOIS, B., CHAN, P., BLOEM, B. R., ADLER, C. H., AND DEUSCHL, G., MDS clinical diagnostic criteria for Parkinson's disease, Movement Disorders, vol. 30, 2015, p. 15911601.

10.MOREIRA, R. C., ZONTA, M. B., ARAUJ O, A. P. S. DE, ISRAEL, V. L., TEIVE, H. A. G., Quality of life in Parkinson's disease patients: progression markers of mild to moderate stages., Arquivos de neuropsiquiatria, vol. 75, 2017, p. 497-502.

11.HAND, A., WILLIAMS, A. J., SCHAPIRA, A. H. V., STOCCHI, F., ABE, K., CHAUDHURI, K. R., MACPHEE, G., NAIDU, Y., BARONE, P., SETHI, K., RYE, D., TLUK, S., TSUBOI, Y., CLAYTON, L., MACMAHON, D., BROWN, R. G., MARTINEZ-MARTIN, P., ODIN, P., BONUCCELLI, U., RABEY, M., THOMAS, S., BREEN, K., ONDO, W., OLANOW, C. W., FORBES, A., Prevalence of nonmotor symptoms in Parkinson's disease in an international setting; Study using nonmotor symptoms questionnaire in 545 patients, Movement Disorders, vol. 22, 2007, p. 1623-1629.

12.GALCEAVA O., MITA A., STANCA D., T., V., LATEA R., G. D., The incidence and the impact of gastrointestinal dyfunctions in Parkinson's disease, Journal of Gastrointestinal and Liver Diseases, vol. Volume 27, 2018, p. 85-86.

13.MUKHERJEE, A., BISWAS, A., DAS, S. K., Gut dysfunction in Parkinson's disease, World J ournal of Gastroenterology, vol. 22, 2016, p. 5742.

14.MAREK, K., ADLER, C. H., LIEPELT-SCARFONE, I., DEUSCHL, G., BERG, D., LANG, A. E., CHAN, P., POEWE, W., OLANOW, C. W., BLOEM, B. R., HALLIDAY, G., GASSER, T., J OSEPH, L., DUBOIS, B., GOETZ, C. G., POSTUMA, R. B., OBESO, J., OERTEL, W., LITVAN, I., STERN, M., MDS research criteria for prodromal Parkinson's disease, Movement Disorders, vol. 30, 2015, p. 1600-1611.

15.POLITIS, M., SAUERBIER, A., LOANE, C., PAVESE, N., MARTIN, A., CORCORAN, B., BROOKS, D. J., RAY-CHAUDHURI, K., PICCINI, P., Sustained striatal dopamine levels following intestinal levodopa infusions in Parkinson's disease patients, Movement Disorders, vol. 32, 2017, p. 235-240.

16.SCHRAG, A., JAHANSHAHI, M., AND QUINN, N., What contributes to quality of life in patients with Parkinson's disease?, Journal of Neurology Neurosurgery and Psychiatry, vol. 69, 2000, p. 308-312.

17.GHEORMAN, V., MILITARU, F., CALBOREAN, V., GHEORMAN, L. M., CHIRITA, A. L., MITA, A., GALCEAVA, O., GHEORMAN, V., STANCA, D., AND UDRISTOIU, I., Clinical and biochemical considerations regarding stress and arrhythmic risk in patients with chronic viral liver diseases, Rev. Chim.(Bucharest), 69, no.4, 2018, p.881

18.LECLAIR-VISONNEAU, L., MAGY, L., VOLTEAU, C., CLAIREMBAULT, T., LE DILY, S., PRETERRE, C., PEYRE, A., DAMIER, P., NEUNLIST, M., PEREON, Y., AND DERKINDEREN, P., Heterogeneous pattern of autonomic dysfunction in Parkinson's disease, Journal of Neurology, vol. 265, 2018, p. 933-941.

19. ALBULESCU, D.M., IONOVICI, N., MOLDOVAN, H.R., et. al., Romanian Journal of Morphology and Embriology, volume 58, issue: 2, pp. 545-551, Published 2017

$\overline{\text { Manuscript received: } 21.12 .2018}$ 